\title{
Eklem içi hiyaluronik asit uygulamasından sonra akut aseptik artrit
}

\section{Acute aseptic arthritis after intraarticular hyaluronic acid}

\author{
Birgül KAÇMAZ1*, Birhan OKTAŞ2, Uğur TiFTiKÇç2, Mahi BALCI³, Serdar GÜL, Ayşegül ASLAN
}

\author{
${ }^{1}$ Kırıkkale Üniversitesi, Enfeksiyon Hastalıkları ve Klinik Mikrobiyoloji AD, Yahşihan, Kırıkkale, \\ ${ }^{2}$ Kırıkkale Üniversitesi, Ortopedi ve Travmatoloji AD, Yahşihan, Kırıkkale, \\ ${ }^{3}$ Kırıkkale Üniversitesi, Patoloji AD, Yahşihan, Kırıkkale, TÜRKiYE
}

\section{öz}

Diz ekleminde gelişen osteoartrit tedavisinde eklem içi hiyaluronik asit (HA) uygulanabilmektedir. Yan etki genellikle görülmemekle birlikte tekrarlayan uygulamalar sonrasında 24-48. saatte nadiren aseptik artrit gelişebilmektedir. Bu raporda ilk kez diz eklemine HA uygulanan bir hastada, 3-4 saatte gelişen, septik artriti taklit eden akut aseptik artrit olgusu sunulmuştur.

Anahtar kelimeler: Aseptik artrit, hiyaluronik asit, osteoartrit

\section{ABSTRACT}

Hyaluronic acid injections in the joint can be used to treat osteoarthritis of the knee. While side effects are rare, for repeated injections, aseptic arthritis can develop 24-48 hours after the injections. In this report, a case of acute aseptic arthritis mimicing septic arhritis, developing in 3-4 hours, is presented for a patient undergoing HA treatment for the first time.

Keywords: Aseptic arthritis, hyaluronic acid, osteoarthritis

\section{Giriş}

Hiyaluronik asit $(\mathrm{HA})$, eklemi çevreleyen sinoviyal sıvı içine salgılanan yüksek molekül ağırlıklı glikozaminoglikandır [1]. Osteoartrit hastalarında sinoviyal sıvının visko elastik özelliğinde düşme ve HA konsantrasyonlarında azalma görülmektedir [2]. HA eklem içi enjeksiyonu 1997 yılından beri diz ekleminde gelişen osteoartrit tedavisinde kullanılmaktadır [3]. Yan etkisi azdır, nadiren uygulamadan sonra enflamatuar reaksiyon ve enjeksiyon yerinde ağrı-şişlik görülebilir [4].

Bu raporda diz eklemine HA uygulanan hastada septik artriti taklit eden akut aseptik artrit olgusu sunulmuştur.

\section{Olgu Sunumu}

Otuz üç yaşında bayan hasta sağ diz ekleminde ağrı ile Ortopedi polikliniğine başvurmuştur. Hastaya 2 yıl önce sağ patella lateral çıkığından dolayı redüksiyon uygulanmış, konservatif tedavi ile takip edilmiştir. Son 5 ayda artan krepitasyon, ağrı, çömelme ve merdiven inip çıkamama şikâyetleriyle tekrar başvurmuştur. Fizik muayenede patellar grinding ve medial fasette palpasyonla hassasiyeti olan hastaya patellofemoral artrit tanısıyla manyetik rezonans görüntüleme tetkiki yapılmış, patellar eklem kıkırdağında mediyal faset düzeyinde grade 4 kondromalazi, femur distal uçta medial kondilin patellar

\footnotetext{
Corresponding Author*: Birgül KAÇMAZ, MD. Kırıkkale Üniversitesi Tıp Fakültesi Enfeksiyon Hastalıkları ve Klinik Mikrobiyoloji AD, Yenişehir, Yahşihan, Kırıkkale, TÜRKIYE 
yüzeyinde kıkırdak defekti saptanmıştır. Artroskopik cerrahiyi kabul etmeyen hastaya fizik tedavi, kinezyo bantlama ve eklem içi HA uygulamasına karar verilmiştir. Aseptik koşullar altında 2 cc sodyum hyaluronat (Variovisc, Nova Medical, Germany) sağ diz eklemine uygulanmıştır. Hasta enjeksiyondan üç saat sonra sağ dizinde hafif şişlik ve kızarıklık fark etmiştir. Ağrı yakınması da bulunan hasta dizine buz uygulaması yapmış ve nonsteroid antienflamatuvar ilaç kullanmıştır. Enjeksiyon uygulamasının 48. saatinde yakınmalarının artması üzerine doktora başvurmuş olan hastanın yapılan fizik muayenesinde sağ dizinde efüzyon (+++), hafif kızarıklık ve hareket kısıtılığı (ekstansiyon: 15, fleksiyon: 100 derece) saptanmıştır. Yüksek ateş şikayeti bulunmayan hastanın hemogram, C reaktif protein (CRP), sedimantasyon tahlilleri istenmiş, eklem aspirasyonu uygulanmıştır. Sinovial sıvının incelenmesinde sıvının pürülan karakterde 48000 lökosit/mm3 (\%90 nötrofil, \%10 lenfosit) içerdiği saptanmış, aerob ve anaerob ekimleri ve gram boyama preparatı yapılmıştır. Hastaya artroskopi ile yıkama ve drenaj yapılarak sinoviyal dokudan patoloji için örnek alınmıştır. Tam kan sayımında beyaz küresi

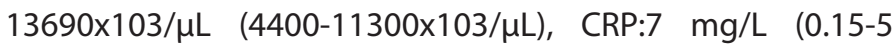
$\mathrm{mg} / \mathrm{L}$ ) ve sedimantasyon hızı $22 \mathrm{~mm} / \mathrm{saat}$ bulunmuş, Gram boyanmış preparatında bakteri görülmemiştir. Akut septik artrit düşünülen hastaya ampirik meropenem ve teikoplanin başlanmıştır. Tedavisinin yedinci gününde patoloji raporu eklem içi HA enjeksiyonuna sekonder gelişen yabancı cisim tipi enflamasyon olarak değerlendirilmiştir. Kültürlerinde üreme saptanmayan hastanın antibiyotik tedavisi durdurulmuştur.

\section{Tartışma}

Aseptik artritin tanısı anamnez, klinik bulgular ve serum laboratuar değerleri ile konamadığı için sıklıkla septik artritle karışabilir [5]. Artritlerin çoğu tipinde klinik benzerdir. Hastalar genellikle akut ağrılı, şiş ve kızarık eklem şikayetleri ile doktora başvururlar. Ateş olabilir. Kesin tanı sinoviyal sıvının laboratuvar incelemeleri ile konulabilir. Aseptik artritte sinoviyal sıvı pürülan görülebilir ama sterildir, gram boyamada mikroorganizma görülmez ve kültür sonucunda da bakteri üremesi saptanmaz [6]. Genellikle kişide altta yatan hastalıklara (örn. Behçet hastalığı, romatoid artrit, gut, pseudogut, reaktif artrit, sistemik lupus eritamatoziste gözlenen lipoartrozis gibi) ikincil olarak aseptik artrit geliştiği bilinmektedir [7].

Literatürde HA uygulamasından sonra aseptik artrit gelişen birkaç olgu raporu bulunmaktadır [8-10]. Idrissi ve ark. [8] ve Ross ve ark. [9] raporladıkları olgularda tekrarlayan intraartiküler HA uygulamasından sonra aseptik artrit geliştiğini, bunda HA'e karşı bireyde gelişen sensitizasyonun, HA yıkım ürünleriyle tetiklenen proenflamatuvar sitokinlerin ve HA'in CD44 reseptörleri ile etkileşimi sonucu lökosit göçüne sebeb olmasının rolü olabileceğini belirtmişlerdir. Bu olgu raporlarında genellikle birden fazla yapılan HA uygulama sonrasında 24-72 saat içinde aseptik artrit gelişebileceği vurgulanmıştır [8-10].

Tahiri ve ark. [11] ise tip 2 diyabeti ve diz ekleminde osteoartriti olan hastada ilk HA enjeksiyonundan sonra aseptik artrit gelişen bir olgu raporlamışlardır. Hasta enjeksiyonun 48. saatinde ekleminde şişlik ve ağrı ile hastaneye başvurmuştur. Bizim olgumuzda da ilk HA uygulamasından sonra aseptik artrit gelişmiştir. Hastamızda eşlik eden sistemik bir hastalık bulunmamaktadır. Enjeksiyondan kısa bir süre sonra (yaklaşık üç saat) hastamızın ekleminde şişlik ve kızarıklık başlamış, 48. saatte şikayetlerinin giderek artması üzerine hastaneye başvurmuştur.

HA enjeksiyonundan sonra gelişen aseptik artritin patojenik mekanizması tam olarak açıklanamamakta, Tip 4 hücre aracılıklı immunolojik olayların bu reaksiyondan sorumlu olabileceği düşünülmektedir. Klinik araştırmalar sonucu eklemde hiyalan antikorların üretimi ve immün hücrelerin alanda birikimi gösterilmiştir. Uygunsuz yapılan enjeksiyon (iğnenin eklem içine yerleştirilememesi gibi) ve HA'in viskösitesinden dolayı sinoviyal sıvı akışının bloke edilmesi de bu durumu açıklayıcı sebepler arasında sayılabilir [12].

Sonuç olarak, eklem içine HA uygulamasının yan etkileri oldukça azdır. Tekrarlayan uygulamalarında nadiren de olsa 24-48. saatte aseptik artrit gelişebildiği gözlenmiştir. Bununla beraber ilk HA uygulamasından üç-dört saat sonrasında da aseptik artrit gelişebileceği bilinmeli, hastalar bu konuda bilgilendirilmeli ve takip edilmelidir.

\section{Maddi Destek ve Çıkar İlişkisi}

Çalışmayı maddi olarak destekleyen kişi/kuruluş yoktur ve yazarların çıkara dayalı bir ilişkisi yoktur.

\section{Kaynaklar}

1. Peyron JG. Intraarticular hyaluronan injections in the treatment of osteoarthritis: state of-the-art review. Rheumatology 1993; 39: $10-5$.

2. Balazs EA, Denlinger JL.Viscosupplementation: a new concept in the treatment of osteoarthritis. J Rheumatol 1993; 39: 3-9.

3. Chen AL, Desai P, Adler EM, Di Cesare PE. Granulomatous inflammation after Hylan G-F 20 viscosupplementation of the knee: a report of six cases. J Bone Jt Surg Am 2002; 84-A(7): 1142-7. 
4. Michou L, Job-DeslandreC, dePinieuxG, Kahan A. Granulomatous synovitis after intraarticular Hylan GF-20. A report of two cases. Joint Bone Spine 2004; 71: 438-40.

5. McColgan BP, Borschke FA. "Pseudoseptic arthritis after accidental intra-articular deposition of the pneumococcal polyvalent vaccine: a case report," Am J Emerg Med 2007; 25: 864e1-864.e3.

6. Call RS, Ward JR, Samuelson CO. Pseudoseptic' arthritis in patients with rheumatoid arthritis. West J Med 1985; 143: 471-3.

7. Oppermann BP, Cote JK, Morris SJ, Harrington T. Pseudoseptic Arthritis: A Case Series and Review of the Literature. Hindawi Publis Corporation Case Reports in Infect Dis 2011: Article ID 942023; 4 pages.

8. Idrissi Z, Benbouazza K, Fourtassi M, et al. Acute pseudo-septic arthritis following viscosuplementation of the knee. P Afr Med J 2012; 12: 44-7.
9. Roos J, Epaulard O, Juvin R, Chen C, Pavese P, Brion JP. Acute pseudoseptic arthritis after intraarticular sodium hyaluronan Joint Bone Spine 2004; 71: 352-4.

10. Leopold SS, Winston J Warme LC, Pettis PD, Shott S. Increased frequency of acute local reaction to intra-articular hylan GF-20 (Synvisc) in patients more than one course of treatment. J Bone Joint Surg 2002; 84: 1619-23.

11. Tahiri L, Benbouazza K, Amine B, Hajjaj-Hassouni N. Acute pseudoseptic arthritis after viscosupplementation of the knee: a case report Clin Rheumatol 2007; 26: 1977-9.

12. Michou L, Job-Deslandre C, Pinieux G, Kahan A. Granulomatous synovitis after intraarticular Hylan GF-20. A report of two cases. Joint Bone Spine 2004; 71: 438-40. 